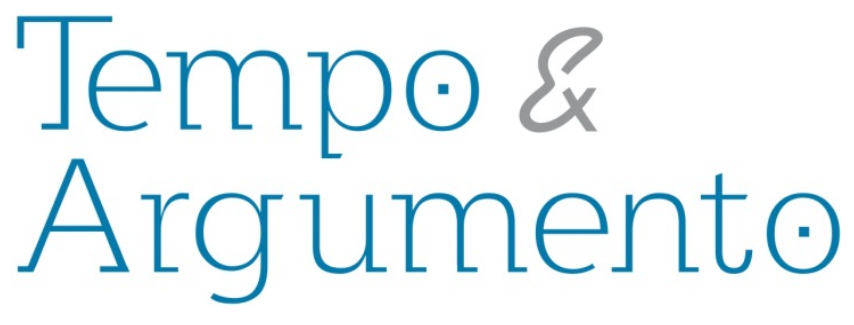

\title{
For showing to U.S. and Brazilian people: a memory of bilateral relations through the social network Flickr
}

\begin{abstract}
This paper investigates the memory of bilateral relations produced by the U.S. Embassy in Brazil on the social network Flickr in the early months of the administration of the Democrat President Barack Obama. The set of images and texts in 19 posts made by the Embassy's profile on the network in the first half of 2009 is analyzed here. It establishes connections between the production of memory, the U.S. political conjuncture, and U.S. political myths, such as Abraham Lincoln and John Kennedy. It also discusses ways of remembering and forgetting several events in bilateral relations throughout the $20^{\text {th }}$ and $21^{\text {st }}$ centuries, besides the positions published on the social network regarding Brazilian politics and history.
\end{abstract}

\author{
João Gilberto Neves Saraiva \\ Universidade Federal do \\ Rio Grande do Norte. \\ Brazil \\ jgilbertons@gmail.com
}

Keywords: Social Networks; Flickr; President - United States.

\section{To cite this translation:}

SARAIVA, João Gilberto Neves. Para americano e brasileiro ver: uma memória das relações

bilaterais através da rede social Flickr. Revista Tempo e Argumento, Florianópolis, v. 6, n. 12, p. 308

- 332, mai./ago. 2014. Original title: Para americano e brasileiro ver: uma memória das relações

bilaterais por meio da rede social Flickr.

DOI: $10.5965 / 2175180306122014308$

http://dx.doi.org/10.5965/2175180306122014308 


\title{
Para americano e brasileiro
} ver: uma memória das relações bilaterais por meio da rede social Flickr

\author{
Resumo \\ Este trabalho investiga a memória das relações \\ bilaterais produzida pela Embaixada dos Estados \\ Unidos no Brasil na rede social Flickr nos primeiros \\ meses de governo do presidente democrata Barack \\ Obama. Analisa-se aqui o conjunto de imagens e \\ textos de 19 postagens realizadas pela embaixada na \\ rede no primeiro semestre de 2009. São \\ estabelecidos elos entre a produção da memória, a \\ conjuntura política norte-americana e mitos políticos \\ estadunidenses, como Abraham Lincoln e John \\ Kennedy. Também problematiza as formas lembrar e \\ esquecer diversos eventos das relações bilaterais ao \\ longo do século $\mathrm{XX}$ e XXI, além dos posicionamentos \\ publicados na rede social em relação à política e à \\ história do Brasil.
}

Palavras-chave: Redes sociais online; Flickr; Presidentes - Estados Unidos. 
Today, time moves at a fast pace. The historic event, forgotten at night, shines on with the dew of a new day and, therefore, it is not in the background of the narrator's story anymore, instead, it is an amazing adventure that unfolds in the background of banality.

(KUNDERA, 1987, p. 19)

In May 2013, the Vice President of the United States made an official three-day visit to Brazil. Joe Biden's schedule consisted in official events in Rio de Janeiro and Brasília, widely reported by newspapers, TV stations, and Brazilian news websites'. Among meetings with officials at the Brazilian Presidential Palace and tours with community leaders at militarily occupied favelas, such as Morro Santa Marta, in the southern zone of Rio's capital city, the news coverage emphasized laudatory pronouncements of the Democrat Vice President regarding the country and bilateral relations. According to an article by João Fellet (2013), while speaking in Brasília, Biden reportedly said: "You have shown the world that there must not be a false choice between development and democracy". In turn, concerning the future of the continent, the Vice President might have predicted:

We may see in the future a middle class, democratic, safe American continent, from the Arctic Circle to the Strait of Magellan. The issue for the United States is not what we can do for the Americas, but what we can do together. And no partner is as significant in this venture as Brazil (QUERO, 2013).

A critical review of bilateral relations reveals various contexts of tension due to which the U.S. government acted so that "its most significant partner" chose development instead of democracy. Researches such as those by Carlos Fico (2008) and James Green and Abigail Jones (2009), for instance, investigate actions, in the name of security and development, taken by the U.S. government to undermine the Brazilian

\footnotetext{
${ }^{1}$ Among them: O Globo <http://oglobo.globo.com/pais/visita-de-vice-presidente-dos-eua-brasilia-quase-viradia-da-fritura-em-programa-oficial-8549483>, Correio Braziliense <http://www.correiobraziliense.com.br/ app/galeria-de-fotos/2013/05/31/interna_galeriafotos,4533/31-5-vice-presidente-norte-americano-visita-obrasil.shtml>, O Estado de São Paulo <http://www.estadao.com.br/noticias/nacional,visita-de-biden-afavela-santa-marta-dura-40-minutos,1037231,0.htm> Access on 17 March 2014.
} 
Rousseff - who welcomed Joe Biden in Brasília. Certainly, these and other conjunctures were not recalled in speeches delivered by the Democrat Vice President during his visit to Brazil.

This paper puts this memory and forgetting into question; it discusses an official memory of bilateral relations constructed by the Democrat administration of President Barack Obama and his Vice President Joe Biden, through publications by the U.S. Embassy in Brazil on the social network Flickr in 2009. Working with a social network on the internet, we think that the digital culture within which it is embedded has introduced new ways of construction, publication, and reception of historical discourses. Thus, we get close to the historian Roger Chartier (2009, p. 59) by reflecting that:

Electronic textuality has, indeed, transformed the way of organizing arguments, historical or not, and the criteria that can mobilize a reader to accept or reject them. [...] It allows an open, fragmented, relational articulation of reasoning, which became possible by the proliferation of hypertextual links.

Within this universe of electronic textuality connections, we are interested in appropriations, the ways of remembering and forgetting events and historical conjunctures in the production of a memory of bilateral relations by the U.S. Embassy, the official body representing the United States and mediating the relations between these countries. We chose to analyze publications on Flickr, a network hosting and sharing photos on the internet since February 2004, which allows users to create the photo albums they want or can share with users inside and outside the network.

The Embassy's profile, on this social network ${ }^{2}$, hosts more than 5,000 photographs, with their captions, hyperlinks, and comments. Within the limits of this paper, we chose the album "Relações bilaterais na história/Historical photos of U.S.-Brazil

\footnotetext{
${ }^{2}$ The profile of the Embassy of the USA in Brazil on Flicker can be accessed here: <http://www.flickr.com/people/embaixadaeua-brasil/> Access on 17 March 2014.
} 
bilateral relations"”. Available since March 2009, this album provides an overview of several official contacts between the countries in the $20^{\text {th }}$ and $21^{\text {st }}$ centuries in 19 posts. Just like the title, the information provided is bilingual - Portuguese and English - in order to serve the audience from both countries.

From the perspective of Ana Maria Mauad (2008, p. 14), we turned these sets of images and texts into sources, thinking of them as social practices that have multiple historical meanings. This way, the photo albums are the products of choice to produce what Mauad (1996, p. 77) calls "narratives engendering memories". Thus, we believe it is pertinent to inquire into the narratives of bilateral relations created on the Flickr album of the Embassy, thinking of them as a constructed social memory. Historian Peter Burke discusses the production of memory. According to the author:

The individuals recall, in the literal, physical sense, but the social groups are those that determine, indeed, what is "memorable", and also the way how something will be remembered. Individuals identify themselves with the significant public events for their group. They "recall" many things not directly experienced. [...] Hence, it is possible to describe memory as a reconstruction of the past (BURKE, 2000, p. 70).

Thus, when producing this social memory, remembering and forgetting are far from being innocent activities. The set of posts on the social network may be thought of, then, as a reconstruction of a past through various principles of selection, interpretation, and distortion of phenomena.

Data from the U.S. Embassy on Flickr inform that the account was created in March 2009. Two months before, Democrats Barack Obama and Joe Biden took their positions, respectively, as President and Vice-President, after eight years of George W. Bush's administration. The creation of the album under analysis dates from the same time; it was among the first ones created on the Embassy's account. Over the next four months it received new publications. In short, it gathers a historical series of relations between the two countries at the time frame from mid-1940s up to the first decade of the $21^{\text {st }}$ century. Dividing it by decades, we have 10 posts - almost half of the album - from the

\footnotetext{
${ }^{3}$ This album can be accessed here: <http://www.flickr.com/photos/embaixadaeuabrasil/sets/72157615306643483/> Access on 17 March 2014.
} 
goes back in time through George Bush, Jimmy Carter, John Kennedy, and Franklin Roosevelt, and then it goes back to actions taken by Obama administration. The first 11 photos in the album constituting this timeline were posted in the first half of March; the 8 others address meetings in the early months of the new Democrat administration and they were posted between April and May.

Historian Ana Maria Mauad (1996, p. 76) highlights the photographic series as a set of possible choices according to a particular world view. An analysis of this set shows the production of a memory of bilateral relations related to the Democratic Party. Out of the 19 posts, only 2 focus on figures of the Republican Party: one is of President George Bush with Lula, in 2007; and the other of the then Secretary of State, Condoleezza Rice, with the Minister of Foreign Affairs, Celso Amorim, during a press conference, in 2008. All other posts refer to governors, advisers, and Democrat politicians on global, regional, or bilateral meetings with Brazilian authorities or to the work of the U.S. Embassy in the country since the arrival of Obama to power. The observation by Cecília Azevedo (2004, p. 2) is pertinent, i.e. the U.S. view of foreign policy as a symbolic place of bipartisan consensus is a myth. The Flickr account of the U.S. Embassy points in this direction, i.e. foreign policy is a battleground where Democrats and Republicans face off by occupying spaces, establishing speeches, and producing memories. 


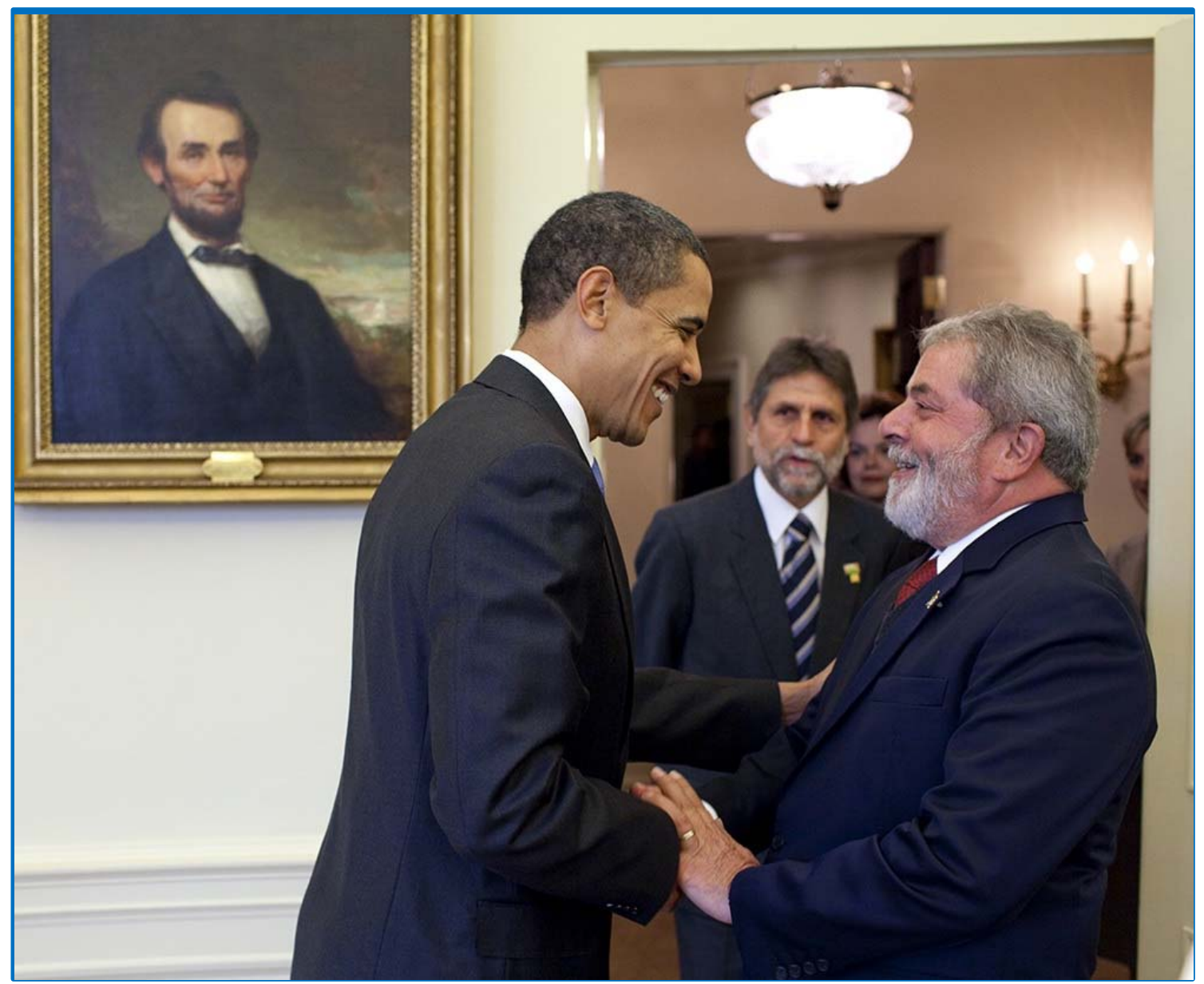

Image 1. Barack Obama greeting the then Brazilian President, Luiz Inácio Lula da Silva ${ }^{4}$.

The first photograph in the album is also its cover; it is a presidential meeting between Barack Obama and Luiz Inácio Lula da Silva. In it (Image 1), both Presidents smile while shaking hands cordially at a hall of the White House. In the background there are other people, such as the then Brazilian Ambassador in the United States, Antônio Patriota, and the then Chief of Staff of the Presidency of the Republic, Dilma Rousseff. In the foreground, above the Presidents, there is the only figure in the composition, which gazes at the photographer, a picture of former President Abraham Lincoln, one of the strongest myths in the U.S. political pantheon. Historian Raoul Girardet (1987, p. 13) points out political myth, among other aspects, as fabulation of reality, with a legendary

\footnotetext{
${ }^{4}$ The photograph was taken by Pete Souza and was published in the White House on 14 March 2009. Available on the Embassy's Flickr here: <http://www.flickr.com/photos/embaixadaeua-brasil/3354935802/in/set$72157615306643483 />$. Access on 17 March 2014. All images used in this work have authorization for integral reproduction for non-profit objectives.
} 
narrative that can be mobilized and has an explanatory function. This way, Lincoln's picture goes beyond the recollection of victory in the Civil War (1861-1865), which maintained the unity of the country, and the approval of the $13^{\text {th }}$ Amendment to the Constitution (1865), which outlawed slavery in the United States, and it acquires a high mythical value able to be mobilized. The mobilization used in the photograph, which associates Abraham Lincoln as a symbol of freedom to Barack Obama, the first black President of the country, is recurrent ${ }^{5}$. In the social memory constructed through Flickr, the mythical $16^{\text {th }}$ President assigns value to actions taken by Barack Obama, while overseeing the good relation between newly installed U.S. government and the Brazilian government.

In that same post, the Embassy's website released a publication of the official White House blog in English, written by Jesse Lee, one of those responsible for digital media in Obama administration. The journalist opens the text by providing a general assessment of the meeting between the Presidents:

Calling himself "a great admirer of the progressivist leader focused on the future that President Lula has proved to be", President Obama opened the press conference, this afternoon, after a meeting between the two heads of State. President Lula described the themes discussed at the meeting, from the containment of global financial crisis in order to face unemployment around the world deriving from it, to the development of Africa and Latin America (LEE, 2009a).

The text aims to report a cordial meeting of leaders who admire each other. A blog post from newly installed Democrat administration points out Lula and Obama as allies who discuss issues of global relevance among themselves and with the press.

By means of data provided in this page on the internet, we find out that almost 2,800 users have accessed it and 5 have added it to their favorites section - this is the publication in the album with the highest number regarding both subjects. This is partly due to the fact that this is the album cover, the image through which the user accesses

\footnotetext{
${ }^{5}$ It is symptomatic, in this sense, the presidential inauguration of Barack Obama, which took place months before the meeting with President Lula in Washington. According to a The New York Times article, he uses the same bible upon which Abraham Lincoln, in his inauguration in 1861,took his oath. Available here: <http://thecaucus.blogs.nytimes.com/2008/12/23/obama-to-take-oath-on-same-bible-aslincoln/?_php=true\&_type=blogs\&_r=0> Access on 17 March 2014.
} 
the other publications, but also used as a dissemination strategy within the network.

The page informs that the Embassy provided the photograph in the groups "USA/Brazil”, "Brasil/Brazil”, and "Brasília/DF" into thematic groups of images, already accessed by over 13,000 users. Thus, it defined the meeting between Lula and Obama as a central image of the memory of bilateral relations and expanded the circulation of this photograph on the social network.

The next post in the series (Image 2) is also a meeting between Presidents; this time, Luiz Inácio Lula and George W. Bush. Unlike the previous photograph, the Presidents do not seem to breathe a cordial atmosphere. Instead of a cordial handshake, there is a cold hug and a certain detachment between them. In the background there are no people or any reference point that may signalize the place where the meeting is being held. The publication's caption merely says that it is in São Paulo, without providing any further detailed information, not even whether it refers to the city or state. While the first photograph highlights a friendly union, surrounded by the U.S. political symbolism, the second was taken from an uncomfortable angle, in which the figures are opposed as they embrace each other.

The third publication in the series, like the previous one, refers to the Republican administration of George Bush. The caption informs that this is an interview attended by Secretary of State Condoleezza Rice and Celso Amorim, then Minister of Foreign Affairs of Lula administration ${ }^{6}$. The caption lacks accurate information; just like the previous publication, it does not express exactly in which part of Brazil the press conference was taking place, it only informed the date (March 13, 2008). As in the previous photograph, people are serious and they do not look at each other. Secretary of State adjusts her earphone, while the Brazilian Minister seems to listen to a question cross-armed. The page on the internet also does not provide these two images with the same investment made to disseminate the first post; they were not included into any Flickr group. Publications received, respectively, so far, 623 and 346 views. No user has added any of these two images as favorites.

\footnotetext{
${ }^{6}$ The publication is available here: <http://www.flickr.com/photos/embaixadaeua-brasil/3407064241/in/set72157615306643483/> Access on 17 March 2014.
} 


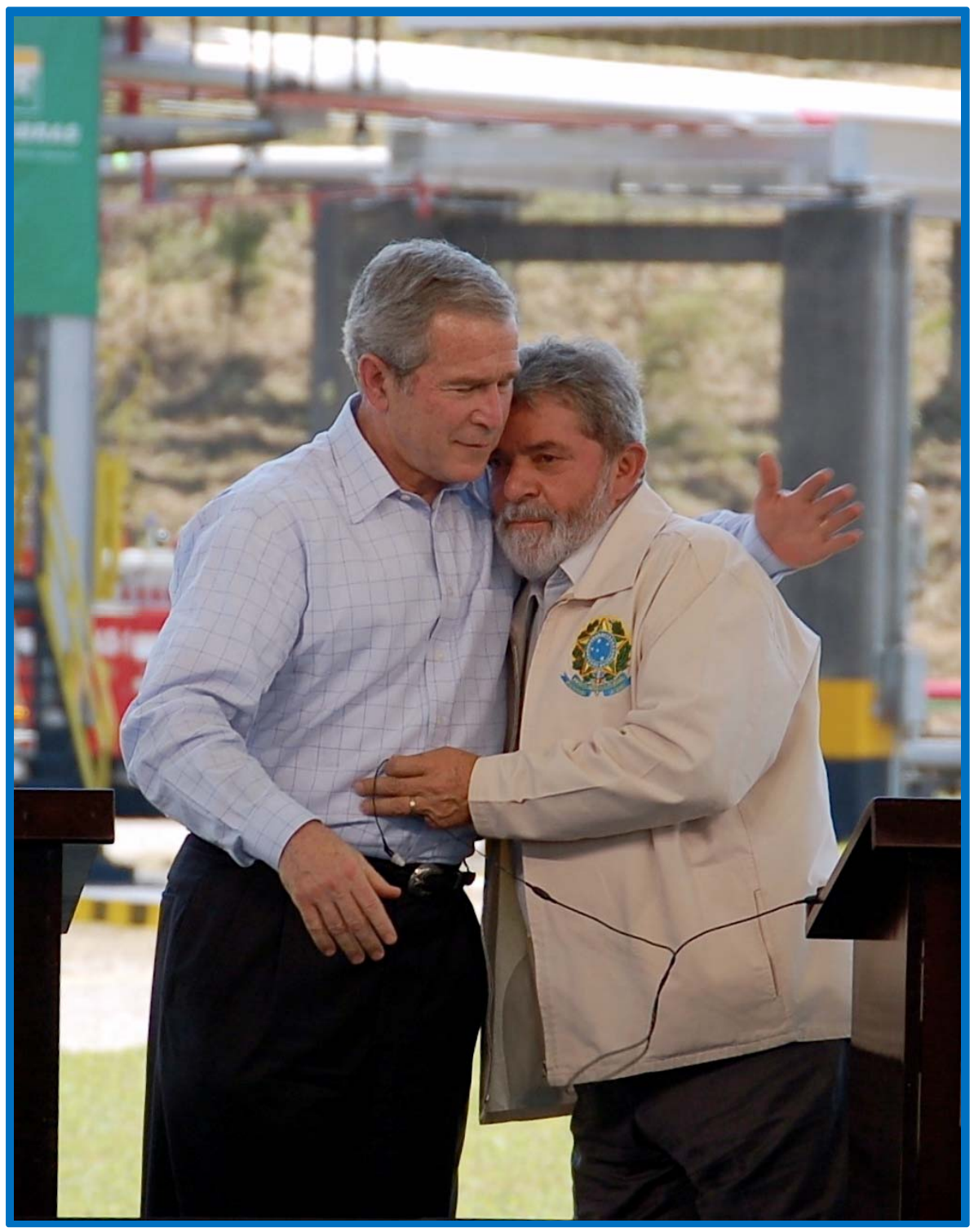

Image 2. The embrace between George W. Bush and Lula in São Paulo7.

We do not believe that the choice of these photos, somewhat uncomfortable for the digital album on the history of bilateral relations, has been made by chance. In the case of meetings between top names in world politics, the events of these two publications had an extensive television and photographic coverage, which created a universe of images available for use. Those responsible for the Embassy's account on the social network could also have "forgotten" the meetings between Lula and George W. Bush administrations, as they did regarding the meetings that took place between

\footnotetext{
${ }^{7}$ The author is not identified; it was taken on 9 March 2007, in São Paulo. It belongs to the collection of the Embassy of the USA in Brazil. Available here: <http://www.flickr.com/photos/embaixadaeua-

brasil/3359263103/in/set-72157615306643483/> Access on 17 March 2014.
} 
Fernando Henrique Cardoso and Bill Clinton, besides many others. However, eliminating these meetings could compromise a key element of the memory of bilateral relations constructed on Flickr since Obama administration: the current Brazilian government. A tour through the album reveals that no less than 10 out of the 19 photographs in the album have someone from the governing coalition of President Lula, usually himself, but sometimes his Ministers and José Sarney, a member of the PMDB and then the President of the Senate. Thinking of the political choices in the context of the inauguration of Obama administration, publications with Bush and Rice work on the social network, within a largely Democrat memory, to stage the work done by the then Brazilian government. Thus, the album addresses Lula administration before the arrival of Obama at the same time that it distinguishes that time from the warmth and joy that would characterize the partnership with the newly elected Democrat.

The fourth publication in the album also goes back to Bush administration, in the timeline followed by the album, in the second half of the 2000s. This image jumps to an official dinner between the Democrat President Jimmy Carter and the President General Ernesto Geisel in 1978 (Image 3). The eight publications in the album dating back to administrations in the $20^{\text {th }}$ century were added to two groups - "History of Brazil" and "USA/Brasil" - totaling just over 50 users on Flickr. These insertions underline a historical nature of posts on the album. As we have seen, the meetings between Democrat Bill Clinton and President Fernando Henrique Cardoso in the 1990 s are not part of the memory produced at the U.S. Embassy's account on Flickr. This lapse is understandable within the set of political choices in the album if we think that, in 2009, the party of FHC PSDB - was opposed to PT administration. Certainly, it would not be polite that the U.S. Embassy recalled the good relations that the Democratic Party had with the current opposition to the Brazilian government, to which newly installed Obama began making contact.

The caption of this publication is among those providing less information in the album. It informs only the country, date, and name of people. It is worth noticing that this caption, laconic, ignores that Geisel, besides being the Brazilian President, was also an Army General. The non-inclusion of any reference to the Military Dictatorship in the memory of bilateral relations is understandable if we consider that, for at least 20 years, 
the Brazilian parties that take control of the federal government define themselves as opposed to the regime established by the 1964 civil-military coup d'État. The publication concerned differs from the others also due to the image format. While the others use the JPEG standard - which holds up to 16 million colors -, even the oldest ones, the fourth is published in the GIF format, with low visual quality. For the dinner held by the General to the Democrat President, and his wife, there was a small image with saturated colors. In this memory, constructed on the internet, the 21-year dictatorship is addressed by silence and oblivion. This way, an absent character stands out: the Democrat Lyndon B. Johnson, who was at the White House between 1963 and 1969. His administration, Michel Weis (1993, p. 166) underlines, continued outlining the 1964 coup, which overthrew João Goulart and led military commanders to seize power in Brazil. While Carter's visit to Geisel, in 1978, is a marginal aspect of this memory, the close relations between the Brazilian dictatorship and Lyndon Johnson administration are completely erased.

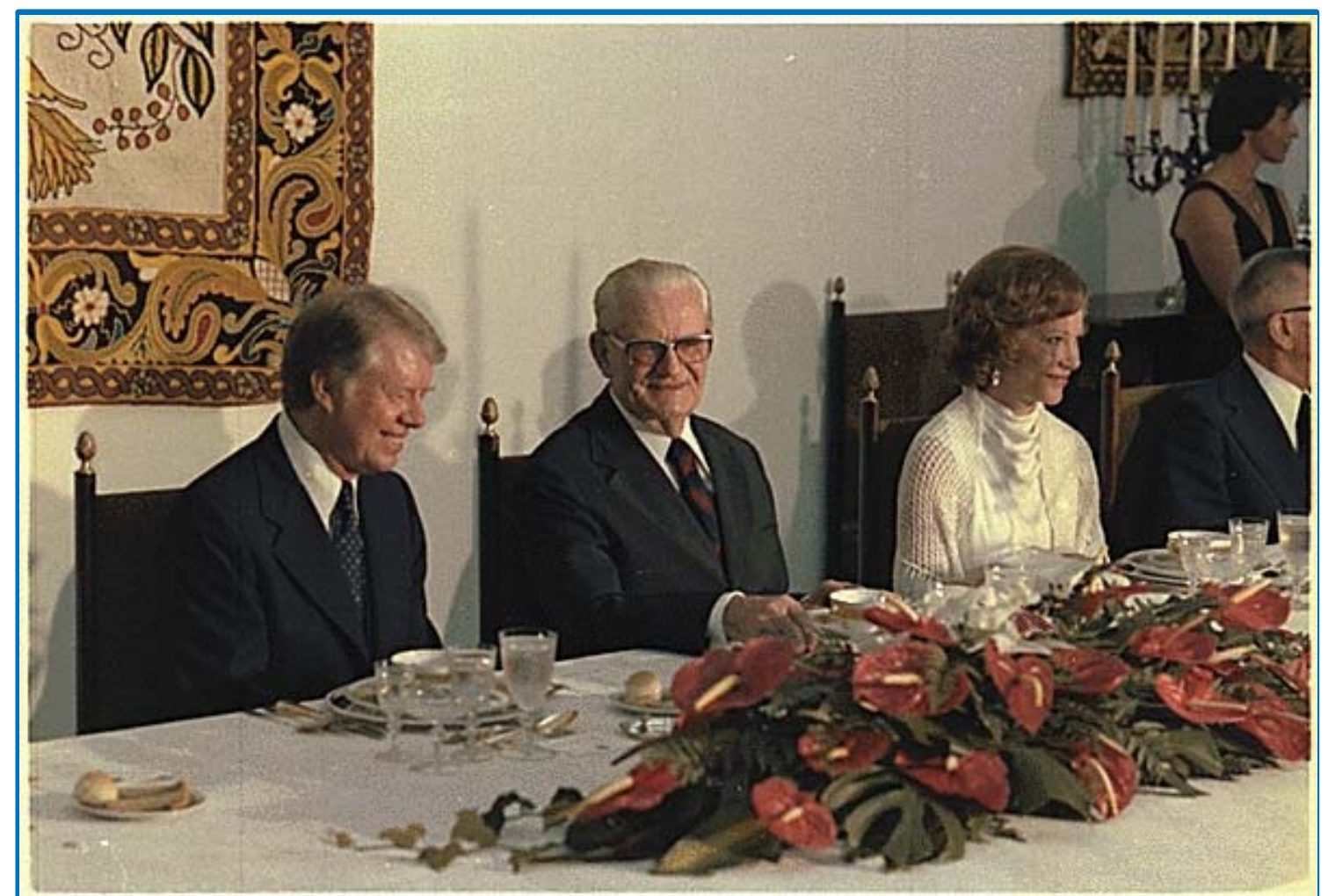

Image 3. Official dinner for the Democrat Carter and General Geisel, the only publication in the album dating back to the time of the Brazilian military dictatorship ${ }^{8}$.

\footnotetext{
${ }^{8}$ The photograph is part of the collection of the White House (the photographer and the original title are not identified). The picture was converted in JPEG format to comply with the requirements of the publication. Available here: <http://www.flickr.com/photos/embaixadaeua-brasil/3359342549/in/set72157615306643483/> Access on 17 March 2014.
} 
In turn, his predecessor occupies a central space in the publications - no less than 5 out of the 19 are dedicated to President John F. Kennedy. They have black and white photographs and detailed information on location, dates, characters and, sometimes, contexts. The first 2 are from April 1962; in them, Kennedy and the Brazilian President João Goulart walk while chatting animatedly, accompanied by an entourage of advisers, ambassadors, and security personnel ${ }^{9}$.

The other three are from 1961 and 1962 and they show the U.S. President receiving South American authorities. In one of them, we see the then Brazilian Ambassador in the United States, Roberto Oliveira Campos; in another one (Image 4), former Presidents Juscelino Kubitschek, from Brazil, and Lerras Camargo, from Colombia - and, lastly, Celso Furtado, head of the Superintendency for the Development of the Northeast (SUDENE) ${ }^{10}$.

The images of energy, youth, charisma, and intelligence keep distinguishing John F. Kennedy, even over fifty years after his death. He was established as a myth in the U.S. political imagination just like what Cecília Azevedo (2007, p. 45) calls hero President. Kennedy is a former President who has captivated the U.S. audience, especially after his death, and his image is associated, in Latin America, with programs such as the Alliance for Progress and the Peace Corps. The work by Henrique Alonso Pereira (2005, p. 26) situates Brazil among the priorities of the foreign policy of the Democrat President and the country that received most attention from these programs. Although there is a critical historiography on Kennedy's legacy, which includes, among others, the aforementioned Alonso Pereira (2005) and Noam Chomsky (1993), stripping the image of peace hero who would promote the end of the Vietnam War if he had not been assassinated, the myth persists and it is constantly updated. The five publications with him, along with those of Barack Obama, are among the most accessed in the album.

\footnotetext{
${ }^{9}$ All photographs of John Kennedy belong to the collection of the White House and have no identification of the photographer. The posts are available, respectively: <http://www.flickr.com/photos/embaixadaeua-brasil/3406980413/in/set72157615306643483/>, <http://www.f lickr.com/photos/embaixadaeua-brasil/3407803796/in/set72157615306643483/> Access on 17 March 2014.

${ }^{10}$ Post available here: $<$ http://www.flickr.com/photos/embaixadaeua-brasil/348 5202617/in/set72157615306643483/> Access on 17 March 2014. <http://www.flickr.com/photos/embaixadaeuabrasil/3406941685/in/set-72157615306643483/> and <http://www. flickr.com/photos/embaixadaeuabrasil/3407727886/in/set-72157615306643483/> Access on 17 March 2014.
} 
Three of them surpass 1,500 views. Four users have added some of the photos to their favorites section.

President John Kennedy always occupies the center of photographs and he is usually smiling, having friendly conversations with politicians and diplomats. The U.S. President is also highlighted by his way of dressing, such as in Image 4: he appears in the album using clear and uncluttered suits - his shirt can be seen - while the others wear closed and dark suits. The set of images of John F. Kennedy used in this memory of bilateral relations refers to a young and good-humored President who gets on well with governors and the Brazilian bureaucratic body. It also refers to someone who knows the Brazilian problems and is able to discuss them with experts, such as Celso Furtado. The halls of the White House, the official residence of U.S. Presidents and symbol of the Federal Power, emerge as the space where these friendly bilateral meetings take place.

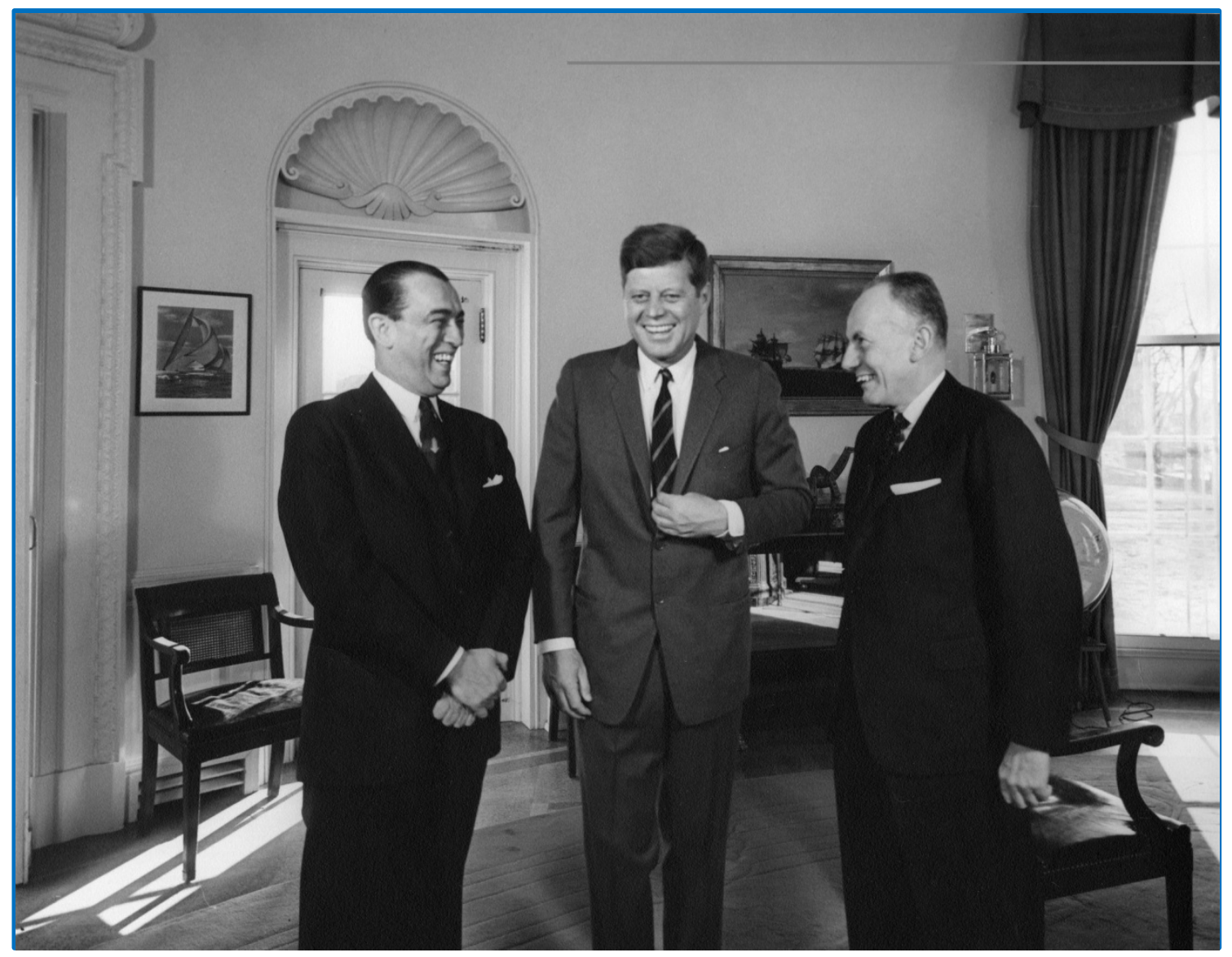

Image 4. The good-humored John F. Kennedy welcomes former Presidents Juscelino Kubitschek (Brazil) and Lerras Camargo (Colombia) in the White House in December $1962^{11}$.

\footnotetext{
${ }^{11}$ The publication can be accessed here: <http://www.flickr.com/photos/ embaixadaeua-
} 
Comparing the publications in the album with photos of Barack Obama, we realize that these and those of John F. Kennedy have many similarities. Such as in Image 1 and also another one in the album ${ }^{12}$, President Obama welcomes the Brazilian President at a hall in his official residence. The U.S. President is shown as a young and charismatic leader, who talks to President Lula at the Oval Office as if they were longtime friends. In the 5 photographs selected to make up the album in which Barack Obama is observed, he is always smiling; in 2 of them, he greets other authorities with a handshake while looking them in the eyes. Just like those of Kennedy, charisma is a key component in the images of Obama published to make up this memory of bilateral relations.

After the posts with photographs of John Kennedy, the historical series on bilateral relations jumps from the early 1960 s to the 1940 s and 1930 s before coming back to the present time. The album silences on the nearly 15 years between World War II and the rise of the hero President whose administration kept Brazil away from its priorities. By taking a global approach to the U.S. foreign policy, Cristina Pecequilo (2005, p. 218) estimates that the U.S. interest has shifted to the reconstruction of Europe and the fight against communism in the Old World, while the Latin American countries tackled the end of the partnership that existed during the war period. Within this period, not covered by the album, there were two official meetings between Presidents Harry Truman, the Democrat who replaced Roosevelt after his death, and Eurico Gaspar Dutra, in 1947 and 1949.

brasil/3370436601/in/set-72157615306643483/> Access on 17 March 2014.

${ }^{12}$ Available here: <http://www.flickr.com/photos/embaixadaeua-brasil/3488662198/in/set-

72157615306643483> Access on: 17 March 2014. 


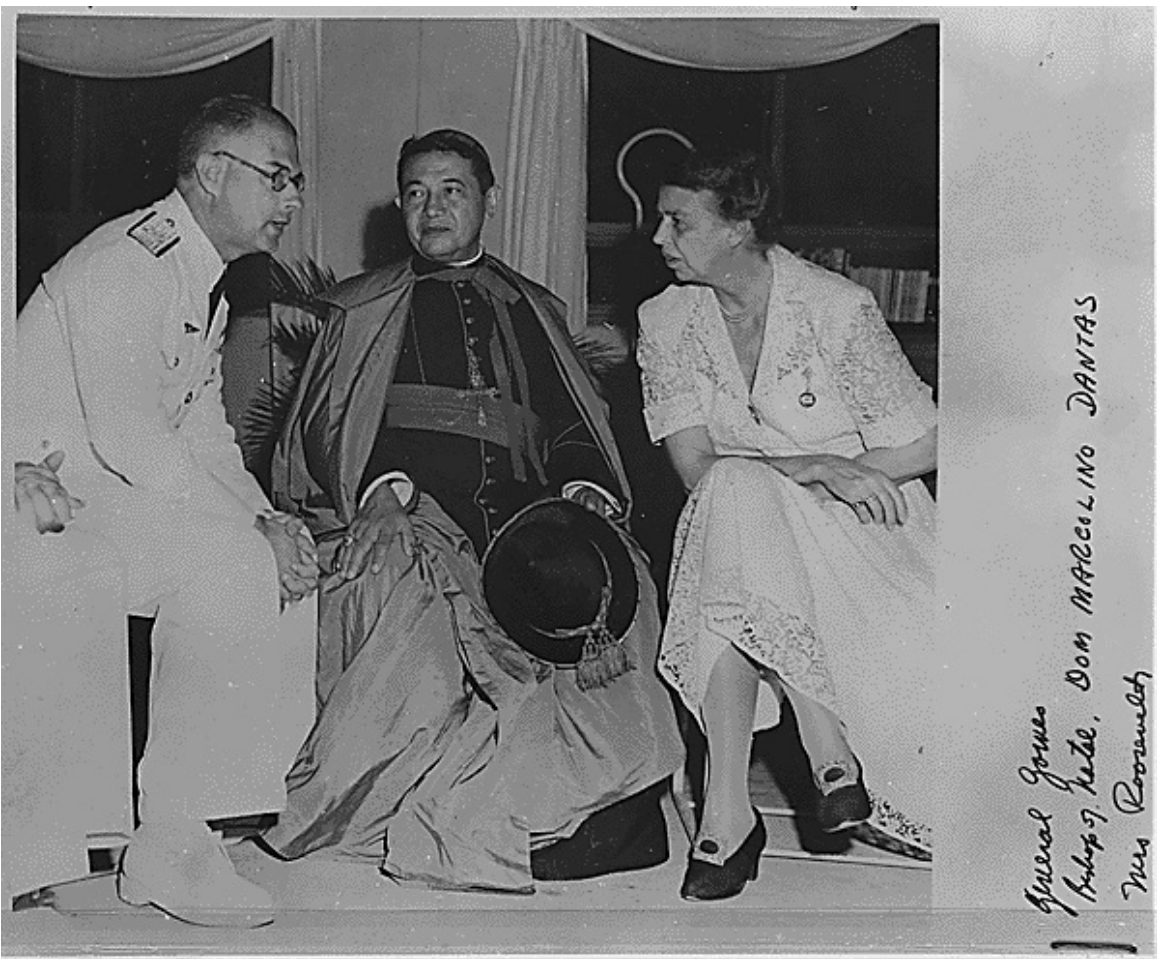

Image 5. Meeting between the first lady Eleanor Roosevelt, Brigadier Gomes, and the Bishop Marcelino in Natal, Rio Grande do Norte, Brazil ${ }^{13}$.

It is pertinent to inquire into the choice of photographs for the time frame of the 1930 s and 1940s, because neither addresses directly World War II, an event in which people usually identify a strong partnership between the U.S. and Brazil. Posts do not provide any information regarding date or any context for the meetings; they only show characters. The first depicts a dinner with Presidents Getúlio Vargas and Franklin Delano Roosevelt ${ }^{14}$; the second (Image 5) portrays the conversation between Brigadier Eduardo Gomes, the Bishop of Natal, Dom Marcelino Dantas, and first lady Eleanor Roosevelt in the capital city of Rio Grande do Norte. The first post gets close to a context depicted by the previous posts: Presidents are sitting at a dinner table and pose smiling for the photo. In the background, a number of unidentified personalities are standing. We are informed

\footnotetext{
${ }^{13}$ The publication makes use of a photograph belonging to the collection of the Library Franklin Delano Roosevelt, without identification of the author. Available here: <http://www.flickr.com/photos/embaixadaeua-brasil/3359321441/in/set-72157615306643483/> Access on 17 March 2014.

${ }^{14}$ The photographer is not identified. The picture belongs to the collection of the Library Franklin Delano Roosevelt. The post can be viewed here: <http://www.flickr.com/photos/embaixadaeuabrasil/3360119258/in/set-72157615306643483/> Access on 17 March 2014.
} 

photograph of a visit by the first lady in March 1944, in the context of World War II. This is 1 out of the 2 posts in the album in which Ambassadors and Presidents leave the scene to give rise to the first lady, the military man, and the bishop.

The choices of photographs and the silence on their context in posts allow us to think that, in the memory of bilateral relations produced on the social network, there is no room for military relations. World War II, for instance, is not part of this memory. There is also no place for dictatorships, such as the New State. The dictatorship headed by Getúlio Vargas between 1937 and 1945 is silenced, just the same way as the military dictatorship established in 1964. Among the choices for the turn of the 1930 s and 1940s, there is a photograph produced a year before the coup d'État, and another, already during the New State, in which the Brazilian dictator and the Democrat President are absent to give room for the dialogue of first lady Eleanor Roosevelt with Brazilian authorities.

The timeline of bilateral relations was constructed through the first 11 posts in the first half of March 2009. In the subsequent months, 8 more were made, which report the work done in the early months of Obama administration. Between late March and April, 4 posts of international meetings were added to the album of bilateral relations. In them, the U.S. President and his Vice President appear along with President Lula in various events, with other heads of State. The 4 publications were added to the groups "Flickr Central Brasil", “Brasil/Brazil", and "USA/Brasil", which amount to about 16,000 members. This groups allowed a wide dissemination among users of the social network. The photos included therein are among the most viewed in the album ${ }^{16}$.

\footnotetext{
${ }^{15}$ Available here: <http://research.archives.gov/description/195820> Access on 17 March 2014.

${ }^{16}$ The four posts have had, until then, respectively and by order of publication, $2.395,772$, 729 and 1.310 views.
} 


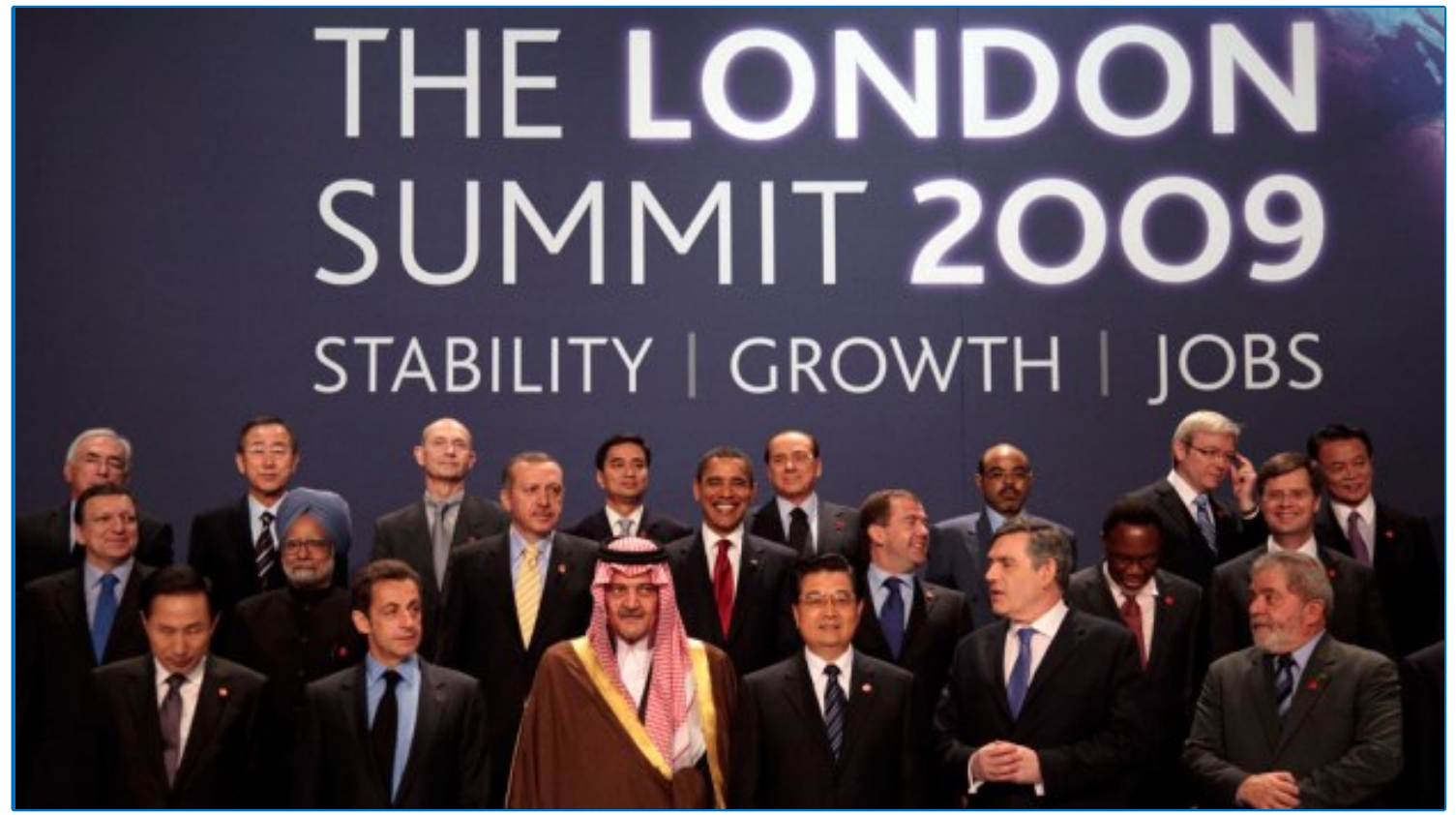

Image 6. G-20 Meeting in London, a group formed by leaders of 19 countries with the largest economies plus the European Union ${ }^{17}$.

The first of these international meetings is that of the Progressive Governance Summit, held in March 2009 in Viña del Mar, Chile. In this post, the Democrat Vice President Joe Biden poses smiling at the center, accompanied by heads of State from Brazil, the UK, Norway, Argentina, Spain, and Uruguay ${ }^{18}$. The next meeting to be registered is the G-20 meeting in April 2009, in London. In this post (Image 6), the Brazilian and U.S. Presidents are with the other heads of State, preparing for the official photo of the event. Barack Obama smiles at the center, surrounded by the leaders of the other countries; the Brazilian President is at the lower right corner. The publication on Flickr provided, among other hypertextual links that are unavailable for access, a link to a post in English on the White House blog ${ }^{19}$. In it, a video is available with the full speech by Barack Obama during the event and some textual clippings of speeches by the U.S.

\footnotetext{
${ }^{17}$ The photograph used in the post is part of the collection of the White House and has no identification of the photographer. The publication on Flicker is available here <http://www.flickr.com/photos/embaixadaeua-brasil/3419012016/in/set-72157615306643483/> Access on 17 March 2014.

${ }^{18}$ The publication uses a photograph without identification of author and title, which belongs to the collection of the White House. Available here: <http://www.flickr.com/photos/embaixadaeuabrasil/3418993944/in/set-72157615306643483> Access on 17 March 2014.

${ }^{19}$ This post in the official blog of the government Obama can be accessed here: <http://www.whitehouse.gov /blog/o9/04/01/Morning-in-London/> Access on 17 March 2014.
} 
President and the host of the event, the then British Prime Minister, Gordon Brown. There is no direct reference to Brazil in them, but both underline Barack Obama lecturing on the themes of the meeting: jobs, growth, and stability.

The subsequent two posts are from the fifth meeting of the Summit of the Americas, held in Trinidad and Tobago, also in April 2009 In the photograph used in the first of them ${ }^{20}$, the U.S. President occupies the center again, a little higher than the other Presidents; Luiz Inácio Lula da Silva is at the lower left corner. In this publication, the Embassy's profile provided another post by Jesse Lee, on the White House blog, which shows in video and text excerpts from the speech delivered by Obama during the event. According to Lee (2009b), at some point of the speech, the U.S. President made the following assessment of inter-American relations:

To move forward, we cannot let ourselves be prisoners of past disagreements. I am very grateful that President Ortega [applause]... I'm grateful that President Ortega do not blame me for things that happened when I was 3 months old [laughs]. Often, an opportunity to construct a new alliance of the Americas has been undermined by obsolete debates. [...] I did not come here to debate the past. I came here to deal with the future [applause]. I believe that, as some of our speakers said, we must learn from history, but we cannot be imprisoned by it.

The album on bilateral relations between the United States and Brazil throughout history is, somewhat, moving in the same direction of Barack Obama's speech. By allocating over half of posts to the administration of newly elected Democrat President, the series seeks, at the same time, to construct a memory through specific key moments of the past and claim the arrival of Obama as a new turning point in the relations with Brazil and other countries of the continent. The next publication on Flickr (Image 7) is also from the Summit of the Americas. In it, Barack Obama and Oscar Arias, the then President of Costa Rica, shake hands cordially under the gaze of the Brazilian President. In the previous set of images, Brazil is included, by means of the presence of President Lula, in the stage of global and regional decisions. In this post, Lula occupies the center of the

\footnotetext{
${ }^{20}$ Publication available here: <http://www.flickr.com/photos/embaixadaeua-brasil/3455878823/in/set72157615306643483/> Access on 17 March 2014.
} 
image, observing the handshake between the U.S. and the Costa Rican Presidents. The Brazilian president is included as a mediator of the relations between the United States and Latin America.

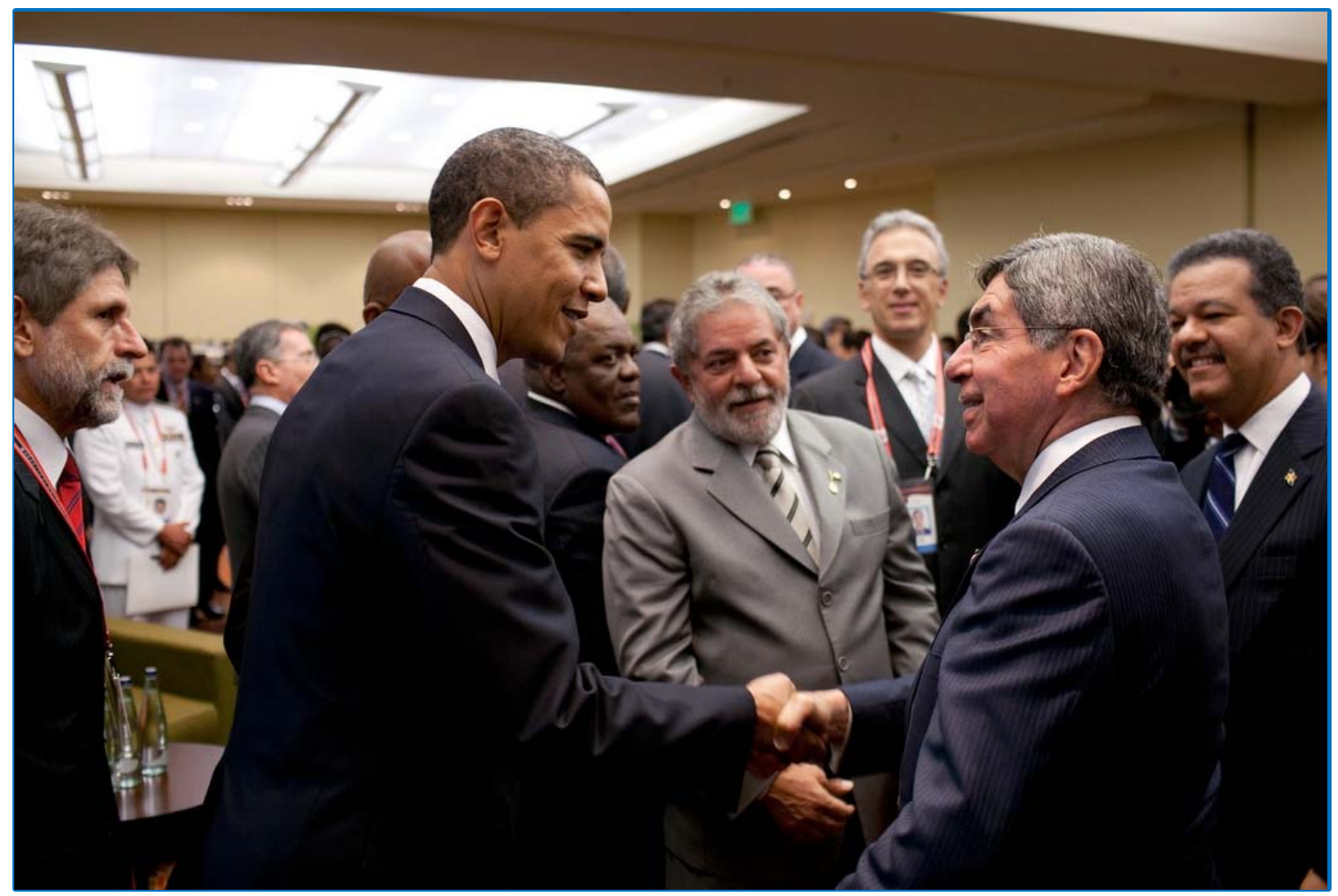

Image 7. Presidents Obama, Lula, and Arias at the Summit of the Americas in Trinidad and Tobago ${ }^{21}$.

The four posts published in sequence on Flickr, with their respective texts and images, allow us to think of a specific view of international relations. In them, the U.S. representative is the key figure, which provides the positions of other leaders with a reference. It claims that the new government is a transformation of the main actor in the scenario of regional and global decisions, the United States. Now, it could seek to forget the misunderstandings of the past to discuss with the other countries, as equals, the actions to be taken in order to develop the continent. These positions are not exactly a novelty. Works like that by Lars Schoultz (2000) show that speeches of inauguration of a new era of inter-American relations, such as that delivered by Obama, are recurrent in the U.S. politics for at least a hundred years. Posts on the Flickr account of the U.S. Embassy

\footnotetext{
${ }^{21}$ Post available here: <http://www.flickr.com/photos/embaixadaeua-brasil/348 5202617/in/set$72157615306643483 />$ Access on 17 March 2014.
} 
indirectly resume at least two of those moments: the administrations of Roosevelt (19331945) and Kennedy (1961-1963).

After publications regarding the international meetings, we have 4 more posts that close the album "Relações bilaterais na história/Historical photos of U.S.-Brazil bilateral relations". The first of them ${ }^{22}$ comes from the same context of the album cover: the visit of the Brazilian President to newly elected Barack Obama. Just like the other, this image shows the Presidents having a friendly conversation, this time sitting in the Oval Office of the White House, with their respective translators. The next post refers to the meeting between José Sarney, currently a Senator allied with PT administration, and Jimmy Carter, in Brasilia, in May 2009. In the photograph, the 2 former Presidents talk side by side at a dinner table. The former Democrat President appears in the album at 2 moments, in what we call the timeline of bilateral relations and working during the Obama administration, in 2009, producing a sense of political continuity in the partnership between the Democratic Party and Brazil. This link is reaffirmed in the subsequent publication, which displays a photograph of the then Brazilian Minister of Foreign Affairs, Celso Amorim, and the Democrat Secretary of State, Hillary Clinton. They are at a bilateral meeting in the Department of American State in February 2009 They pose standing, looking at each other, each in front of the respective country's flag ${ }^{23}$. The three posts constitute a set where equivalent representations of Lula and Obama administrations dialogue, first the Presidents, then former Presidents, and finally top diplomats.

The last post was made in late May 2009. It is the only in the album to depict the work of representatives of the U.S. Embassy in Brazil. In it, Brazilian children from the project “Educate dancing" pose with their teacher and two employees from the Embassy: Lisa Kubiske, business supervisor, and Adele Ruppe, advisers for education, culture, and press $^{24}$. This photograph is the pioneer of the most common type of publication on Flickr;

\footnotetext{
${ }^{22}$ The post is available here: <http://www.flickr.com/photos/embaixadaeua-brasil/3488662198/in/set$72157615306643483 />$ Access on 17 March 2014.

${ }^{23}$ The publication presents a photograph by Jonathan Ernst of the collection of Reuters. Available here: <http://www.flickr.com/photos/embaixadaeua-brasil/3886608455/in/set-72157615306643483/> Access on 17 March 2014.

${ }^{24}$ Post available here: <http://www.flickr.com/photos/embaixadaeua-brasil/3588511761/in/set-
} 
the photographic coverage of visits by U.S. authorities to Brazil, such as the visit by Vice President Joe Biden in May $2013^{25}$.

The profile of the U.S. Embassy in Brazil keeps producing new publications, introducing new characters, themes, and contexts to its collection on the Internet. By conducting a historiographical analysis of one of its albums, this paper investigated the production of an official memory of bilateral relations with Brazil, by means of posts on the social network Flickr, getting close, this way, to issues of social memory to inquire into what Milan Kundera's poetic language calls amazing adventure, in which the narrator appropriates historical events. Thus, we identify various political configurations that permeate the strategies of forgetting and remembering at many diplomatic meetings held over the $20^{\text {th }}$ and $21^{\text {st }}$ centuries.

The first of them addresses a predominantly Democrat memory, which leaves few spaces for Republicans elements. The second is a memory attentive to the political situation of Brazil, which affirms Lula's PT administration while forgetting, for instance, the partnership between the two administrations of President Fernando Henrique Cardoso (1995-2002) and the military commanders, who seized power in 1964. Forgetfulness comprises all times since the late 1930s, when, somehow, Brazil was not among the U.S. political priorities, except in the final years of Roosevelt administration (1936-1945) and during the brief Kennedy administration (1961-1963). In this memory there is no space for world conflicts, such as World War II and the Cold War, although these events permeate much of the affairs in the memory of bilateral relations.

Through images and texts in the posts, we take contact with the strategy of working with consolidated myths in U.S. politics, such as Abraham Lincoln and John

72157615306643483/> Access on 17 March 2014

${ }^{25}$ The following address has all the albums posted by the profile of the Embassy in the social network: <http://www.flickr.com/photos/embaixadaeua-brasil/sets/>. For the album of Biden's visit to Brazil, see: <http://www.flickr.com/photos/embaixadaeua-brasil/sets/72157633833109615/> Access on 17 March 2014. 
Kennedy, to assert a new administration. By the way, this is a crucial component of this and other political memories. It recovers the historical events in a specific way, which allows setting a present time. This way, the Flickr account of the U.S. Embassy sets the past so that the smiling Barack Obama can show up as a novelty in bilateral relations, based on the best facts and events of previous times, so that Joe Biden, after his official visit, could rise up to the skies through memories of friendly talks and laudatory speeches towards Brazilian authorities.

\section{Referências}

AZEVEDO, Cecília. Culturas políticas em confronto: a política externa norte-americana em questão. In: ENCONTRO DA ASSOCIAÇÃO NACIONAL DE PESQUISADORES DE HISTÓRIA LATINO AMERICANA E CARIBENHA, VI, Local do evento, 2004. Anais... Maringá: ANPHLAC, 2004.

AZEVEDO, Cecília. Em nome da América: os corpos de paz no Brasil. São Paulo: Alameda, 2007.

BURKE, Peter. Variedades de história cultural. Rio de Janeiro: Civilização Brasileira, 2000.

CHARTIER, Roger. A história ou a leitura do tempo. Belo Horizonte: Autêntica, 2009.

CHOMSKY, Noam. Camelot: os anos Kennedy. São Paulo: Scritta, 1993.

FELLET, João. Vice de Obama fecha visita ao país com afagos ao Brasil. In: BBC Brasil.[internet] São Paulo, 29 maio 2013. Disponível em <http://www.bbc.co.uk/portuguese/noticias/2013/05/130530_biden_mdb_jf.shtml> Acesso em: 17 mar. 2014.

FICO, Carlos. O grande irmão - da operação Brother Sam aos anos de chumbo: o governo dos Estados Unidos e a ditadura militar brasileira. Rio de Janeiro: Civilização Brasileira, 2008.

GIRARDET, Raoul. Mitos e mitologia políticos. São Paulo: Companhia das Letras, 1987. 
GREEN, James; JONES, Abigail. Reinventando a história: Lincoln Gordon e as suas múltiplas versões de 1964.In: Revista Brasileira. História., v. 29, n. 57, p. 67-89, 2009.

KUNDERA, Milan. O livro do riso e do esquecimento. Rio de Janeiro: Nova Fronteira, 1987.

LEE, Jesse. President Obama: a wonderful meeting of the minds. In: The White House Blog [Internet], Washington, 14 mar. 2009a. Disponível em $<$ http://www.whitehouse.gov/blog/og/03/14/president-obama-a-wonderful-meeting-ofthe-minds/> Acesso em: 17 mar. 2014.

LEE, Jesse. To learn from History, not be trapped by it. . In: The White House Blog [Internet], Washington, 18 abr. 2009b. Disponível em $<$ http://www.whitehouse.gov/blog/og/04/18/To-Learn-from-History-Not-Be-Trapped-byIt/> Acesso em: 17 mar. 2014.

MAUAD, Ana Maria. Através da imagem: fotografia e história interfaces. Tempo, Rio de Janeiro, v. 1, n. 2, p. 73-98, 1996.

MAUAD, Ana Maria. Poses e flagrantes: ensaios sobre história e fotografia. Niterói: Editora UFF, 2008.

PECEQUILO, Cristina Soreanu. A política externa dos Estados Unidos. Porto Alegre: UFRGS, 2005 .

PEREIRA, Henrique Alonso de A. R. Criar ilhas de sanidade: os Estados Unidos e a aliança para o progresso no Brasil. 2005. Tese (Doutorado) - Pontifícia Universidade Católica, São Paulo, 2005.

QUERO, Caio. No Rio, Biden diz que Brasil não é mais emergente e tem novas responsabilidades. In: BBC Brasil [internet], São Paulo, 29 maio, 2013. Disponível em <http://www.bbc.co.uk/portuguese/noticias/2013/05/130529_biden_no_rio_pai_cq.shtml> Acesso em: 17 mar. 2014

SCHOULTZ, Lars. Estados Unidos: poder e submissão: uma história da política norteamericana em relação à América Latina. Bauru: EDUSC, 2000.

WEIS, W Michael. Cold warriors and coups d'etat: Brazilian-American relations 1945-1964. Albuquerque: University of New Mexico Press, 1993. 
Recebido em 31/03/2014 Aprovado em 21/06/2014

Universidade do Estado de Santa Catarina - UDESC Programa de Pós-Graduação em História - PPGH Revista Tempo e Argumento Volume 06 - Número 12 - Ano 2014 tempoeargumento@gmail.com 